\title{
BIOCHEMICAL COMPOSITION OF THE HOPS AND QUALITY OF THE FINISHED BEER
}

\author{
Anatolii Bober, Mykola Liashenko, Lidiia Protsenko, Natalia Slobodyanyuk, Liudmyla Matseiko, \\ Nadiia Yashchuk, Sergiy Gunko, Mikhailo Mushtruk
}

\begin{abstract}
The large varieties of hops and hop products used in the brewing industry. Various in the biochemical composition, individual approaches to the brewing technology of each hop product are required in order to obtain a high-quality beer with a characteristic bitter taste and aroma. The purpose of this work was to study the biochemical composition of pressed conical hops, pellets of hop type 90, type 45, ethanolic and $\mathrm{CO}_{2}$ extracts of hop of various varieties, and their influence on the quality of the finished beer.

As a result of comprehensive research on hops and hop products of various varieties, using the modern biochemical methods were determined differences in their biochemical composition depend on the absolute values such parameters as the mass fraction of $\alpha$-acids, $\beta$-acids and their composition, xanthohumol, general polyphenols, essential oils, the ratio of their valuable components of hops: $\beta$-acids to $\alpha$-acids and also for quantity of general polyphenols, essential oils per unit of $\alpha$-acids. Based on the results of the biochemical composition of hops and hop products were investigated their influence on the quality of beer and were determined their using in brewing.
\end{abstract}

Keywords: Hops, Products, Beer, Biochemical, Composition

\section{INTRODUCTION}

One of the main and irreplaceable type of raw material for brewing is hop. Its constituent substances gives beer a specific taste and aroma, promote foam formation and stability quality of beverage. The quality of hop and hop products do not depend on only the quality of beer, but also on the efficiency of brewing production in general. The quality of hop do not directly relate only with varietal characteristics and conditions of cultivation, but also with conditions of post-harvest handling and storage (Lyashenko, 2002; Pavlovič et al., 2012).

High-quality beer with characteristic bitter taste and aroma obtains only with the use of hops and hop products with a certain biochemical composition. At the same time, the efficiency of extraction, isomerization and transformation of separate numerous hop compounds in the process of boiling beer wort is very important (Protsenko et al., 2012).

The using of hop and their products in the brewing is due to the fact that its cones contain large quantity of biologically active substances such as bitter substances, polyphenols and essential oils. Specific substances give to beer a unique bitterness and a specific aroma, participate in the clarification and formation of foam, increase its stability during storage (Protsenko et al., 2018).
The beer production in Ukraine and in the world increasing that stimulates the demand for hop products and necessitates the balanced development of the industry for satisfaction of the brewing industry. However, in a competitive struggle on the market, the winner is not the one who produces more but average hops, but the one who makes it better in quality and cheaper in the price. Even under the current difficult conditions, there are opportunities and reserves for the production of highquality commodity hops, including aromatic (Bober et al., 2015).

For brewing used about $90 \%$ of hop and hop products. The demand for hop is constantly increasing, but the industry is far from satisfying the domestic market. Currently, the Ukrainian brewing industry used up to $20 \%$ of domestic production. The main part of raw materials is imported, which create dependence on world market conditions. This industry divide inter countries such as Germany, Czech Republic, Poland, Austria, USA, Canada, Australia and China (Pryimachuk et al., 2018).

As marketing research has shown to the world market delivered only about $10 \%$ of natural cones hops but $90 \%$ of granulated and hop processed into extracts from total amount of obtained hop products. Only in the brewery of low-power remained classical beer production technology, 
where for brewing beer wort traditionally used pressed hops. Powerful breweries of Ukraine transferred to using different types of pellets, ethanolic and $\mathrm{CO}_{2}$-extracts of hops (Zheplinska et al., 2019).

The most rational way of processing hop cones is to granulate them. Only this technology provides for a more complete save of all complex of valuable substance hops for a long time before application in the production of beer, more stable use, high quality of the finished product. The most popular and promising are pellets type 90, which according to the chemical composition practically do not differ from the native cones of hops.

Pellets type 45 apply to enriched hop products. They differ significantly in the biochemical composition from native hops, since the amount of polyphenols per unit of alpha acids is halved, and their production associated with additional losses of essential oils. For brewing properties, it is intermediate product between cones and $\mathrm{CO}_{2}$-extract. Granulated hops are also more convenient to use for packing and adding to wort. In addition, the volumetric mass of granulated hops is much smaller than compressed, thus reducing transport and storage costs (Zheplinska et al., 2019). Another way that make it possible to keep bitter and other valuable substance hops in the unchanged state, it is production of hops extracts with using organic and inorganic solvents. The expediency of producing hop extracts is conditioned by the possibility of obtaining highquality and efficient products that can be stored for a long time without changing their biochemical composition (Protsenko and Litvynchuk, 2017).

However, despite the fact that in the world more than 90 $\%$ of native (cone) hops processed into hop products, there is absent of scientific research about quality hop varieties which have different content and composition of bitter substances, polyphenols and essential oils. The specialists in agriculture and the brewing industry need to know the main advantages and disadvantages of these products and their impact on the quality of the finished beer, especially as in the literature, especially in advertising, as a rule, they write more about their advantages, without emphasizing the disadvantages.

The purpose of this work was to study the biochemical composition of hops and hop products during 2012 - 2017 of various hop varieties and their impact on the quality of the finished beer.

\section{Scientific hypothesis}

Studies of hops and hop products of different breeding varieties with using modern biochemical methods will supply to establish differences in their biochemical composition. Peculiarities of the biochemical composition of hop products will allow individually to approach the brewing technology of each hop product in order to obtain high quality beer with a characteristic bitter taste and aroma.

\section{MATERIAL AND METHODOLOGY \\ Samples}

For researches, cones of pressed hops and pellets of type 90 typical representatives of the aromatic group of varieties (Slavyanka, Nationalny, Zagrava) and bitter (Alta, Hercules) which widespread in the production conditions of Ukraine, were used; pellets type 45 varieties Tradition and Spalt Select; ethanol and $\mathrm{CO}_{2}$-extracts of the Hercules variety of foreign production.

Beer from the samples of hop products was manufactured at the mini brewing biochemistry department of hop and beer of the Polissya Institute of Agriculture of the National Academy of Agrarian Sciences of Ukraine with the output of 100 litres, which adequately reflects the conditions of real breweries.

The hop and hop products added on the mini brewery added on the content of $\alpha$-acids in them.

The wort was prepared from $100 \%$ barley malt. The norm of hop was calculated in the amount of $50 \mathrm{mg}$ of bitter substances per $1 \mathrm{dm}^{3}$ of wort. Duration of wort boiling with hop products was 90 minutes.

\section{Methods}

Modern international physical-chemical methods of determining the quality indices of hops and hop products and products of their transformation in the brewing process were used: high-performance liquid chromatography, spectrophotometry and also methods of quality control of beer wort and finished beer, harmonized with the methods of the European Brewery Convention (Jaskula, et al., 2007).

The content and composition of $\alpha$ - and $\beta$-acids and xanthohumol were determined by high-performance liquid chromatography. Chromatography was performed using Ultimate 3000 liquid chromatograph with a UV detector at a temperature of $35{ }^{\circ} \mathrm{C}$ of the method described in state standard of Ukraine 14164:2019 (DSTU EN 14164:2019). The $100 \times 0.0021 \mathrm{~m}$ column was used which was filled with a Pinacle sorbent DV E18 $3 \mu$. As a mobile phase, a solution of methanol, water and acetonitrile was used in the ratio of $38: 24: 38$. For the quantitative determination of xanthohumol was used standard-ethanol of xanthohumol with containing $99.8 \%$ of this compound and for $\alpha-$ and $\beta$ acids used the international standard franchise (ISF-3) (Jaskula, et al., 2007).

The amount of essential oil was determined by the Ginsberg method (Lyashenko, 2002). The qualitative composition of the essential oil was determined by the gasliquid chromatography method on 50-60 m capillary quartz columns of chromatograph "Crystal $2000 \mathrm{M}$ ". The total amount of polyphenolic compounds and proanthocyanidins was determined by photometric methods in the modification of M.I. Lyashenko (Lyashenko, 2002).

The index of oxidation of bitter substances in hops and hop products was determined by extraction of bitter substances with the following definition on spectrophotometer in an extract of an optical density of oxidized components at wavelength was $275 \mathrm{~nm}$, and aand $\beta$-acids at a wavelength was $325 \mathrm{~nm}$ (Lyashenko, 2002).

In beer wort and beer, bitterness was determined by spectrophotometric method of EBC. The method is based on the determination of the optical density of isooctane obtained by removing bitter substances from acidified wort or beer from isooctane (2,2,4-trimethylpentane), with used wavelength is $275 \mathrm{~nm}$. The magnitude of the bitterness expressed by units of the international scale with determining bitterness according to EBC which was 
evaluated on the based the index of optical density. The content of polyphenolic compounds in the wort and beer, were measured on a spectrophotometer according to EBC 8.11 and EBC 9.11. (Kábelová-Ficová et al., 2017).

The quality of beer was evaluated organoleptically by tasting of tasting commission according to the requirements for beer according to the branch Instruction by the 25-point integrated estimation (Punčochářová et al., 2019).

\section{Statistic analysis}

The mathematical processing of the data was performed with using the method of dispersion (ANOVA) analysis using the programs Statistica 10 and Microsoft Office 2010 .

\section{RESULTS AND DISCUSSION}

Complex biochemical studies of hops and hop products of various varieties with the use of modern biochemical methods (high performance liquid chromatography) made it possible to establish that hops and hop products of different varieties have different biochemical composition and hence a different brewing value.

The biochemical characteristic of the widespread hop products in the brewing industry was presence in Table 1 .

The most valuable compounds of hops and their processing products are bitter substances. Bitter substances are unique and do not presence in the other plants. The most important among the bitter substances are alpha acids, which converted into iso-alpha acids, the main compounds of bitterness of beer, during the process of isomerization at boiling of beer wort.

When added to beer of fresh hops, almost $90 \%$ of bitterness of beer is formed as a result of isomerisation of alpha acids in iso-alpha acids (Malowicki and Shellhammer, 2006). The quantity of alpha acids is the main pricing factor for the evaluation of hops and hop products. The content of $\alpha$-acids in the studied hop products changed from 3.82 to $52.83 \%$ (Table 1). The highest content of $\alpha$-acids was found in the $\mathrm{CO}_{2}$-extract of the Hercules variety $-52.83 \%$. Among pellets, this index was the maximum in pellets of hop type 90 bitter grade Hercules $-13,64 \%$.

Beta-acids are not bitter in taste, but in the process of oxidation compounds are formed having a pleasant bitterness. One of their main properties is a high antiseptic effect, which important for increasing the biological stability of beer during storage. Therefore the beta-fraction of hops abroad used in the processing of sugar beets to improve their storage in sugar factories (Lyashenko, 2002). Depending on the variety and type of hops, the content of $\beta$-acids ranges from 3.41 till $18.81 \%$.

As the researches shown, hop pellets of type 90 of domestic production contain the whole complex of necessary for brewing substances and equivalent to hop cones. Characteristic feature of cones hop and pellets of type 90 and type 45 , in particular of aromatic varieties, is the high positive coefficient of aromatics between the content of $\beta$ - and $\alpha$-acids which ranged from 0.89 till 1.79. This is a main feature in the estimation of the brewing quality of hops and hop products. On average, conducting research in $2012-2017$ the higher indicator of aromatics were characterized as cones and hop pellets of the Slavyanka and Nationalny varieties. Unlike, the coneshaped and granulated hop of aromatic varieties, cones and pellets of hops of bitter varieties, characterized by a sharp aroma and high content of $\alpha$-acids. The ratio of $\beta$-acids to $\alpha$-acids in the cones and pellets of hop of bitter varieties and extracts was less than 1. From 0.26 in hop pellets type 90 of the Hercules variety to 0.53 in hop pellets type 90 of the Alta variety.

Application of high-performance liquid chromatography in our studies allow to established the quantitative and qualitative composition of bitters substances of hops and hop products of various grades (Figure 1, Figure 2 and Figure 3). On the presented chromatograms the composition of bitters substances of the studied hop products clearly shows the difference in their quantitative and qualitative composition. The chromatograms of the composition of bitters substances of investigated hop products, we can see difference between quantitative content of a- and $\beta$-acids, and in their composition. The composition of the $\alpha$ - and $\beta$-acids, depending on the type of hop cones and the type of hops, changed significantly, and the first it related with the content of cohumulon in the $\alpha$-acids and the colupulon in $\beta$-acids. Thus, the mass fraction of cohumulon in the a-acid content ranged from 22.72 till $38.62 \%$, and the colupulon - from 42.61 till $59.22 \%$. As a rule, if more contained in the a-acid cohumulon, than the higher the content of the colupulon was in the $\beta$-acids.

The composition of a- and $\beta$-acids is important for the production of high-quality beer. The most quality for brewing has hops with mass fraction of cohumulon in the composition of a-acids does not exceed $30 \%$. Hops with content cohumulon of $40-50 \%$ in alpha acids used mainly for the preparation of isomerized preparations, because it is not used in the natural form for the production of beer (Malowicki and Shellhammer, 2006).

Brewers pay particular attention the index of oxidation of bitters substances, because they consider it one of the main indicators of the quality of cones of hops and hop products. This index on a par with the content of alpha acids controlled during the purchase of consignments of hop and hop products. Than the lower index of oxidation of bitters substances then the higher were quality of hop products (Michałowska, 2017).

According to Table 1, the index of oxidation during the years of investigation, both in cones, pellets hops, and hop extracts, fluctuated within $0.27-0.50$. The minimum index of oxidation is set in the $\mathrm{CO}_{2}$ extract -0.27 but the maximum in the pellets type 90 of hop Slavyanka variety 0.50 and did not exceed the norms of normative documents. It was established that the index of oxidation in the hop pellets was not higher than it was in the cones of hop. This indicates that the quality of the pellets of the hops type 90 is practically the same as the cones hops but the quantitative and qualitative composition of the bitter substances depends on the variety from which they obtained.

The data which we received about the content of xanthohum in the biochemical composition of hops and hop products of various varieties deserved attention (Table 1, Figure 1, Figure 2 and Figure 3). 
Table 1 Biochemical characteristics of hops and hop products for brewing.

\begin{tabular}{|c|c|c|c|c|c|}
\hline $\begin{array}{c}\text { Samples of hops and hop } \\
\text { products }\end{array}$ & a-acids, $\%$ & $\begin{array}{c}\text { Kohumulon } \\
\text { within } \\
\alpha \text {-acids, \% }\end{array}$ & $\beta$-acids, $\%$ & $\begin{array}{c}\text { Colupulon within } \\
\beta \text {-acids, } \%\end{array}$ & $\begin{array}{c}\text { Ratio of } \\
\alpha / \beta-\text { acids } \\
\text { (method } \\
\text { EBC 7.7) } \\
\end{array}$ \\
\hline $\begin{array}{l}\text { Cones of hops of the } \\
\text { Slavyanka variety }\end{array}$ & $3.82 \pm 0.04 \mathrm{a}^{*}$ & $22.72 \pm 1.16 \mathrm{a}$ & $5.42 \pm 0.07 \mathrm{a}$ & $42.63 \pm 0.86 \mathrm{a}$ & $1.79 \pm 0.02 \mathrm{a}$ \\
\hline $\begin{array}{l}\text { Cones of hops of the } \\
\text { Nationalny variety }\end{array}$ & $5.40 \pm 0.08 \mathrm{~b}$ & $25.31 \pm 0.98 \mathrm{ab}$ & $5.43 \pm 0.09 \mathrm{a}$ & $44.30 \pm 1.10 \mathrm{ab}$ & $1.15 \pm 0.08 \mathrm{~b}$ \\
\hline $\begin{array}{l}\text { Cones of hops of the } \\
\text { Zagrava variety }\end{array}$ & $5.71 \pm 0.14 \mathrm{c}$ & $24.03 \pm 1.23 \mathrm{ab}$ & $4.72 \pm 0.05 \mathrm{~b}$ & $42.61 \pm 0.65 \mathrm{a}$ & $1.06 \pm 0.05 \mathrm{c}$ \\
\hline $\begin{array}{l}\text { Cones of hops of the Alta } \\
\text { variety }\end{array}$ & $8.83 \pm 0.06 \mathrm{~d}$ & $24.52 \pm 0.80 \mathrm{ab}$ & $4.03 \pm 0.02 \mathrm{c}$ & $44.82 \pm 0.72 \mathrm{ab}$ & $0.52 \pm 0.01 \mathrm{~d}$ \\
\hline $\begin{array}{l}\text { Pellets of type } 90 \\
\text { Slavyanka variety }\end{array}$ & $4.64 \pm 0.12 \mathrm{e}$ & $25.21 \pm 0.76 \mathrm{ab}$ & $4.22 \pm 0.06 \mathrm{ec}$ & $43.42 \pm 0.88 \mathrm{ab}$ & $1.28 \pm 0.04 \mathrm{e}$ \\
\hline $\begin{array}{l}\text { Pellets of type } 90 \\
\text { Nationalny variety }\end{array}$ & $6.30 \pm 0.09 \mathrm{fi}$ & $25.62 \pm 1.08 \mathrm{~b}$ & $5.13 \pm 0.10 \mathrm{~d}$ & $43.54 \pm 1.18 \mathrm{ab}$ & $1.17 \pm 0.05 \mathrm{~b}$ \\
\hline $\begin{array}{l}\text { Pellets of type 90Zagrava } \\
\text { variety }\end{array}$ & $6.41 \pm 0.10 \mathrm{f}$ & $24.32 \pm 0.68 \mathrm{ab}$ & $4.32 \pm 0.08 \mathrm{ec}$ & $44.80 \pm 1.22 \mathrm{ab}$ & $0.92 \pm 0.08 \mathrm{f}$ \\
\hline $\begin{array}{l}\text { Pellets of type } 90 \\
\text { Alta variety }\end{array}$ & $10.1 \pm 0.08 \mathrm{~g}$ & $28.31 \pm 1.34 \mathrm{c}$ & $4.33 \pm 0.04 \mathrm{ec}$ & $46.22 \pm 0.78 b$ & $0.53 \pm 0.02 \mathrm{~g}$ \\
\hline $\begin{array}{l}\text { Pellets of type } 45 \\
\text { Tradition variety }\end{array}$ & $8.20 \pm 0.04 \mathrm{~h}$ & $26.22 \pm 1.12 b c$ & $6.32 \pm 0.08 \mathrm{f}$ & $45.32 \pm 0.65 \mathrm{ab}$ & $0.92 \pm 0.10 \mathrm{f}$ \\
\hline $\begin{array}{l}\text { Pellets of type } 45 \text { Spalt } \\
\text { Select variety }\end{array}$ & $6.23 \pm 0.13 \mathrm{fi}$ & $24.81 \pm 1.10 \mathrm{ab}$ & $4.32 \pm 0.05 \mathrm{ec}$ & $43.34 \pm 1.08 \mathrm{ab}$ & $0.89 \pm 0.11 \mathrm{f}$ \\
\hline $\begin{array}{l}\text { Pellets of type } 90 \text { Hercules } \\
\text { variety }\end{array}$ & $13.64 \pm 0.12 \mathrm{j}$ & $33.33 \pm 1.62 \mathrm{~d}$ & $3.41 \pm 0.04 \mathrm{~g}$ & $54.04 \pm 1.36 \mathrm{c}$ & $0.26 \pm 0.07 \mathrm{~h}$ \\
\hline $\begin{array}{l}\text { Ethanol extract hops of } \\
\text { the Hercules variety }\end{array}$ & $41.82 \pm 0.10 \mathrm{k}$ & $38.50 \pm 1.74 \mathrm{e}$ & $17.02 \pm 1.11 \mathrm{~h}$ & $59.22 \pm 1.20 \mathrm{~d}$ & $0.38 \pm 0.05 \mathrm{i}$ \\
\hline $\begin{array}{l}\mathrm{CO}_{2} \text {-extract hops of the } \\
\text { Hercules variety }\end{array}$ & $52.83 \pm 0.071$ & $38.62 \pm 1.42 \mathrm{e}$ & $18.81 \pm 1.10 \mathrm{i}$ & $59.13 \pm 1.05 \mathrm{~d}$ & $0.34 \pm 0.04 \mathrm{i}$ \\
\hline minimum & 3.82 & 22.72 & 4.03 & 42.61 & 0.34 \\
\hline maximum & 52.83 & 38.62 & 18.81 & 59.22 & 1.79 \\
\hline mean & 13.38 & 27.81 & 6.73 & 47.18 & 0.86 \\
\hline $\begin{array}{c}\text { Samples of hops and hop } \\
\text { products }\end{array}$ & $\begin{array}{c}\text { Oxidation index, } \\
\mathbf{I}_{0} \\
\end{array}$ & $\begin{array}{c}\text { General } \\
\text { polyphenols, \% }\end{array}$ & $\begin{array}{c}\text { Essential oil, } \\
\mathrm{mg} / \mathbf{1 0 0} \mathrm{g}\end{array}$ & Xanthohumol, \% & - \\
\hline $\begin{array}{l}\text { Cones of hops of the } \\
\text { Slavyanka variety }\end{array}$ & $0.34 \pm 0.01 \mathrm{a}$ & $5.02 \pm 0.12 \mathrm{a}$ & $0.78 \pm 0.05 \mathrm{a}$ & $0.35 \pm 0.02 \mathrm{a}$ & - \\
\hline $\begin{array}{l}\text { Cones of hops of the } \\
\text { Nationalny variety }\end{array}$ & $0.37 \pm 0.01 \mathrm{~b}$ & $5.53 \pm 0.08 \mathrm{~b}$ & $0.48 \pm 0.05 \mathrm{~b}$ & $0.49 \pm 0.01 \mathrm{~b}$ & - \\
\hline $\begin{array}{l}\text { Cones of hops of the } \\
\text { Zagrava variety }\end{array}$ & $0.33 \pm 0.01 \mathrm{a}$ & $6.62 \pm 0.14 \mathrm{c}$ & $0.67 \pm 0.02 \mathrm{c}$ & $0.35 \pm 0.01 \mathrm{a}$ & - \\
\hline $\begin{array}{l}\text { Cones of hops of the Alta } \\
\text { variety }\end{array}$ & $0.36 \pm 0.00 \mathrm{ab}$ & $5.94 \pm 0.10 \mathrm{~d}$ & $1.22 \pm 0.04 \mathrm{~d}$ & $0.25 \pm 0.03 \mathrm{c}$ & - \\
\hline $\begin{array}{l}\text { Pellets of type } 90 \\
\text { Slavyanka variety }\end{array}$ & $0.50 \pm 0.02 \mathrm{c}$ & $6.03 \pm 0.05 \mathrm{~d}$ & $0.36 \pm 0.07 \mathrm{e}$ & $0.40 \pm 0.02 \mathrm{~d}$ & - \\
\hline $\begin{array}{l}\text { Pellets of type } 90 \\
\text { Nationalny variety }\end{array}$ & $0.41 \pm 0.03 \mathrm{~d}$ & $4.92 \pm 0.18 \mathrm{a}$ & $0.51 \pm 0.08 \mathrm{~b}$ & $0.49 \pm 0.04 \mathrm{~b}$ & - \\
\hline $\begin{array}{l}\text { Pellets of type 90Zagrava } \\
\text { variety }\end{array}$ & $0.45 \pm 0.01 \mathrm{e}$ & $6.54 \pm 0.06 \mathrm{c}$ & $0.49 \pm 0.02 \mathrm{~b}$ & $0.40 \pm 0.02 \mathrm{~d}$ & - \\
\hline $\begin{array}{l}\text { Pellets of type } 90 \\
\text { Alta variety }\end{array}$ & $0.40 \pm 0.02 \mathrm{~d}$ & $4.52 \pm 0.05 \mathrm{e}$ & $0.87 \pm 0.04 \mathrm{f}$ & $0.35 \pm 0.02 \mathrm{a}$ & - \\
\hline $\begin{array}{l}\text { Pellets of type } 45 \\
\text { Tradition variety }\end{array}$ & $0.47 \pm 0.01 \mathrm{e}$ & $11.03 \pm 0.07 \mathrm{f}$ & $0.22 \pm 0.05 \mathrm{~g}$ & $0.52 \pm 0.01 \mathrm{~b}$ & - \\
\hline $\begin{array}{l}\text { Pellets of type } 45 \text { Spalt } \\
\text { Select variety }\end{array}$ & $0.49 \pm 0.02$ ce & $9.92 \pm 0.18 \mathrm{~g}$ & $0.33 \pm 0.03 \mathrm{~h}$ & $0.45 \pm 0.03 \mathrm{~b}$ & - \\
\hline $\begin{array}{l}\text { Pellets of type } 90 \text { Hercules } \\
\text { variety }\end{array}$ & $0.37 \pm 0.03 \mathrm{~b}$ & $4.21 \pm 0.04 \mathrm{e}$ & $0.52 \pm 0.02 \mathrm{~b}$ & $0.45 \pm 0.02 \mathrm{~b}$ & - \\
\hline $\begin{array}{l}\text { Ethanol extract hops of } \\
\text { the Hercules variety }\end{array}$ & $0.40 \pm 0.01 \mathrm{~d}$ & - & $0.75 \pm 0.01 \mathrm{a}$ & $2.10 \pm 0.05 \mathrm{e}$ & - \\
\hline $\begin{array}{l}\mathrm{CO}_{2} \text {-extract hops of the } \\
\text { Hercules variety }\end{array}$ & $0.27 \pm 0.02 \mathrm{f}$ & - & $2.5 \pm 0.06 \mathrm{i}$ & - & - \\
\hline minimum & 0.27 & 4.21 & 0.22 & 0.25 & - \\
\hline maximum & 0.50 & 11.03 & 2.50 & 2.10 & - \\
\hline mean & 0.40 & 6.40 & 0.75 & 0.55 & - \\
\hline
\end{tabular}

Note: *value \pm SD are means of three repetitions, *Mean values followed by different letters are statistically different at $p<0.05$. 

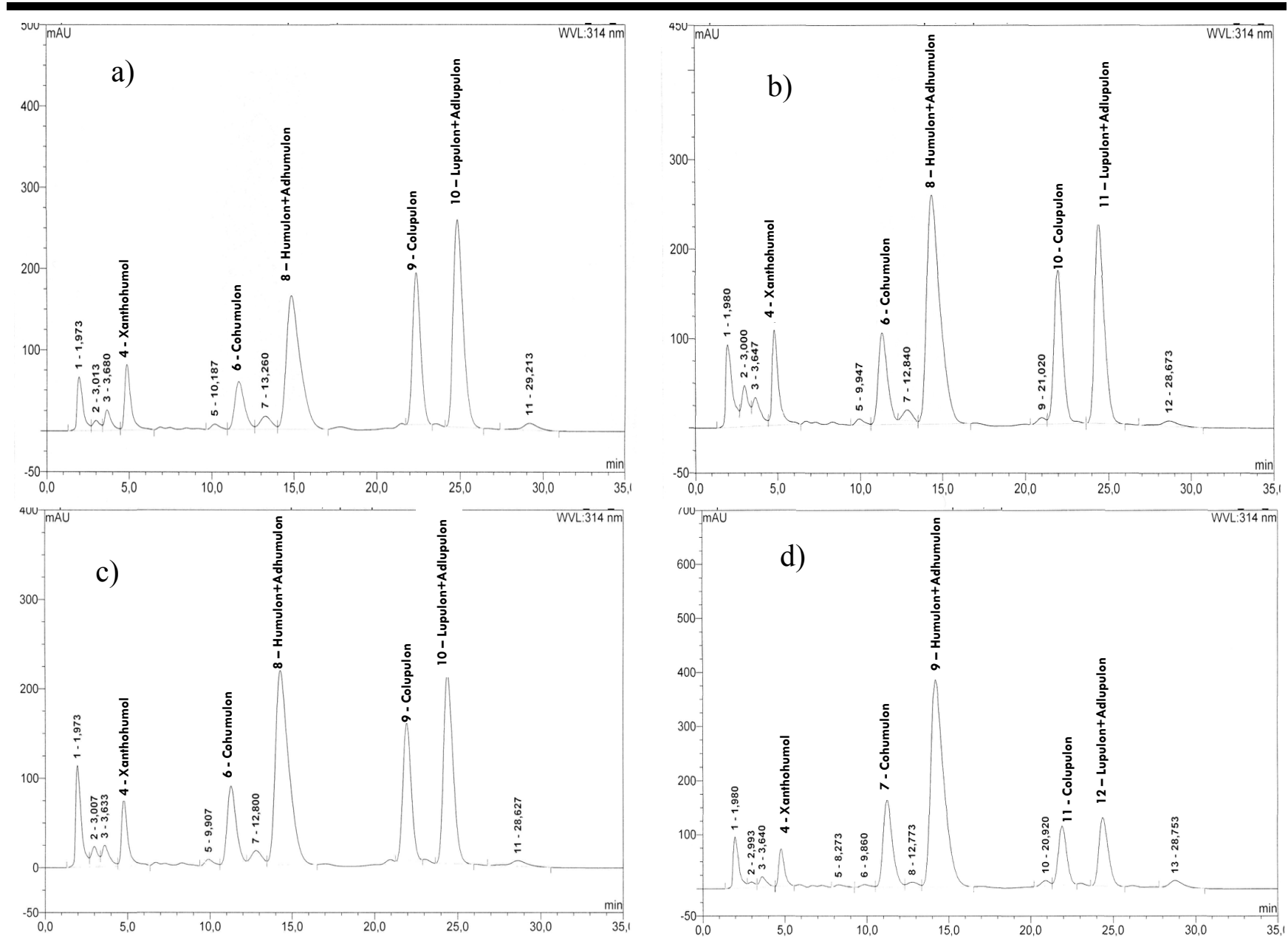

Figure 1 Chromatograms of the composition of bitters substances of cones of hops of various varieties: a) Slavyanka variety; b) Nationalny variety; c) Zagrava variety; d) Alta variet.

Depend on the variety of hops and the type of hops products, the amount of xanthohumol ranged from 0.25 till $2.10 \%$.

The highest content of xanthohumol was found in the ethanol extract of Hercules $(2.10 \%)$ and pellets of hop type 45 of the Tradition variety $(0.52 \%)$. The quantity of xanthohum in hops and hop products independent from content of bitter substances in the $\alpha$-acids and $\beta$-acids were established.

Thus, in the cones and pellets of the type 90 of the bitter Alta variety with a high content of $\alpha$-acids, the content of xanthohumol was smallest, which indicate on the absence correlation between the content of $\alpha$-acids and xanthohumol.

As we seen from the chromatogram (Figure 3), in the biochemical composition of the $\mathrm{CO}_{2}$ extract of variety Hercules xantohumol was absence.

According to literary sources (Lyashenko, 2009), at the production of ethanol extract it contains at least $90 \%$ of prenylflavonoids (including xanthohumol) of hop but at the production of $\mathrm{CO}_{2}$-extract, these substances are practically not extracted and remain in the wastes.

Nowadays in the world there are intensive scientific researches about medicinal properties of this compound.

The experimental data obtained concerning the therapeutic effect of xanthohumol indicate that it was quite effective in the treatment of fungi, staphylococci, streptococcus, herpes and hepatitis viruses and has anti- cancer properties. Xanthogumol has negative affect on cancer cells of a person with a diagnosis of large intestine, breast, ovaries, prostate and leukemia, and does not affect on the healthy cells, activates enzymes that inhibit tumor growth, neutralizes the effect of enzymes that contribute to their growth, inhibit the growth of metastases (Ferk, et al., 2010; Yang et al., 2013). The anti-carcinogenic effect of xanthohumol associated with its high antioxidant properties. Such an assessment of the effect of xanthohumulin was confirmed in the German Cancer Center (Shanina et al., 2019).

In the process of beer preparing xanthohumol converted into isoxantohumol, which also has anti-carcinogenic properties (Żolnierczyk, et al., 2017). However, the anticarcinogenic action of isoxantohumol is $10 \%$ less than xanthohumol. At wort preparation about $70 \%$ of xanthohumol converted to isoxantohumol and in the finished beer left only $30 \%$.

Therefore, brewers need to pay attention to this when developing technologies for making beer and soft drinks with high content of xanthohumol and isoxantohumol for the prevention of cancer. With aim increasing xanthohumol in the beer have to add to beer at wort process hop products with high content of xanthohumol and also it added at the end of beer boiling for prevent the process of isomerization of this component. 

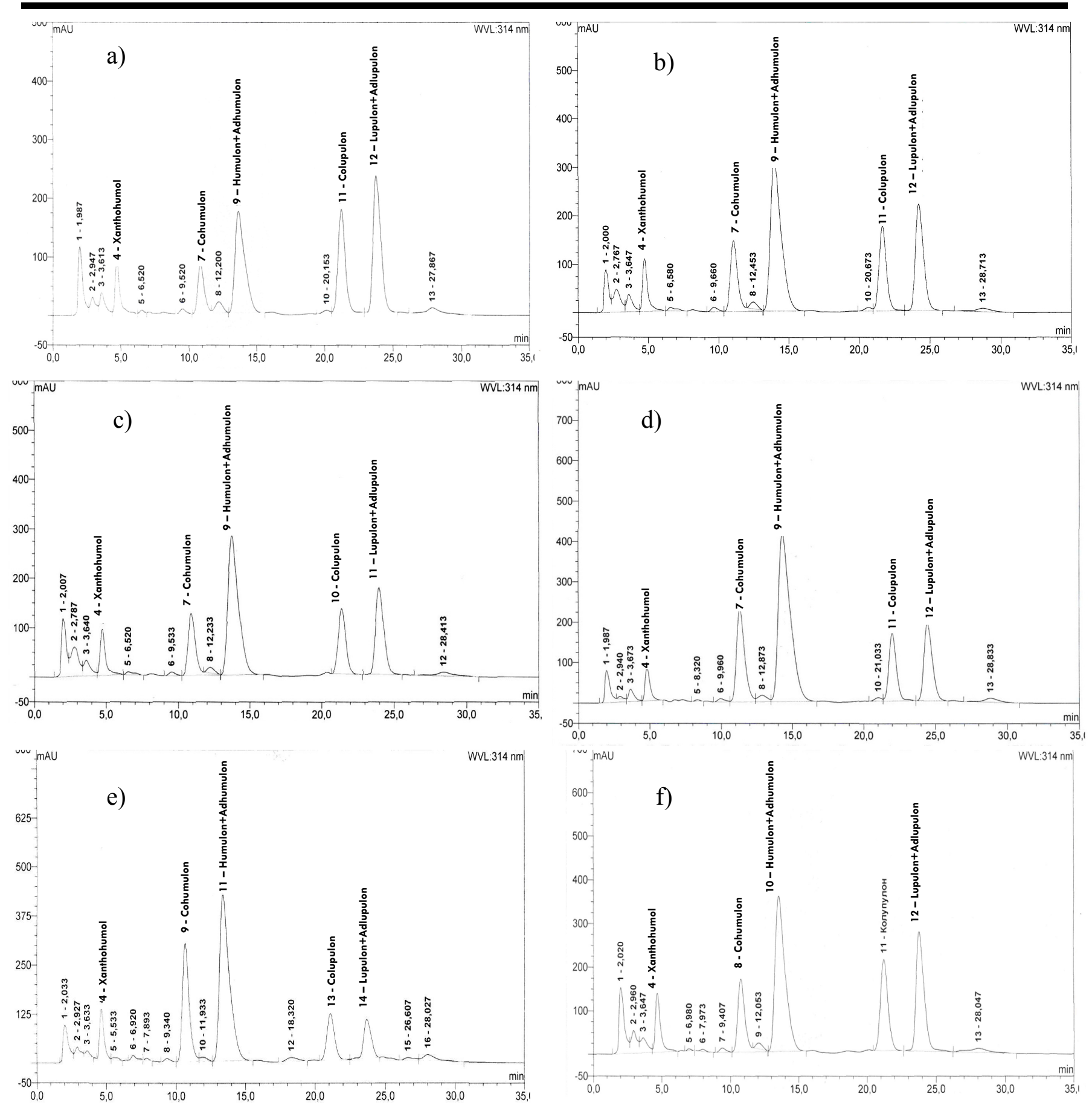

Figure 2 Chromatograms of the composition of bitters substances of pellets of hops: a) Pellets of type 90 Slavyanka variety; b) Pellets of type 90 Nationalny variety; c) Pellets of type 90 Zagrava variety; d) Pellets of type 90 Alta variety; e) Pellets of type 90 Hercules variety; f) Pellets of type 45 Tradition variety.

According to the results of the conducted researches (Table 1), the content of essential oils in the hop products was from 0.22 till $2.5 \mathrm{mg} .100 \mathrm{~g}^{-1}$. The highest content of essential oils was found in the $\mathrm{CO}_{2}$ extract of hop of the Hercules variety. However, in brewing, in addition to the content and qualitative composition of essential oils have quantity of essential oil per $1 \mathrm{~g}$ of $\alpha$-acids since the quantity of hops applied to beer calculated taking into account the content of $\alpha$-acids.

On the contrary pellets and extracts, in cones of hops it is possible to see more quantity of essential oil per $1 \mathrm{~g}$ of $\alpha$ acids, which provides more aromatic beer. For obtain the beer with a good hop flavour, it is necessary to use hops with content of essential oil at least $0.2 \mathrm{~mL}$ or about $50 \mu \mathrm{L}$ sesquiterpenes per $1 \mathrm{~g}$ of $\alpha$-acids (Lyashenko, 2002; Pavlovič et al., 2012; Michałowska, 2017).

The organoleptic properties of beer made from different hop products also affect the different content of polyphenolic compounds. Along with the bitter substances, polyphenols have an important role in the forming of completeness and purity of the taste of the beverage, and also directly affect the freshness and stability of beer during storage. Hop polyphenols interact with high molecular proteins of wort, form complexes that fall into the precipitate and thus improve the clarification of wort and beer (Goiris et al., 2014). 

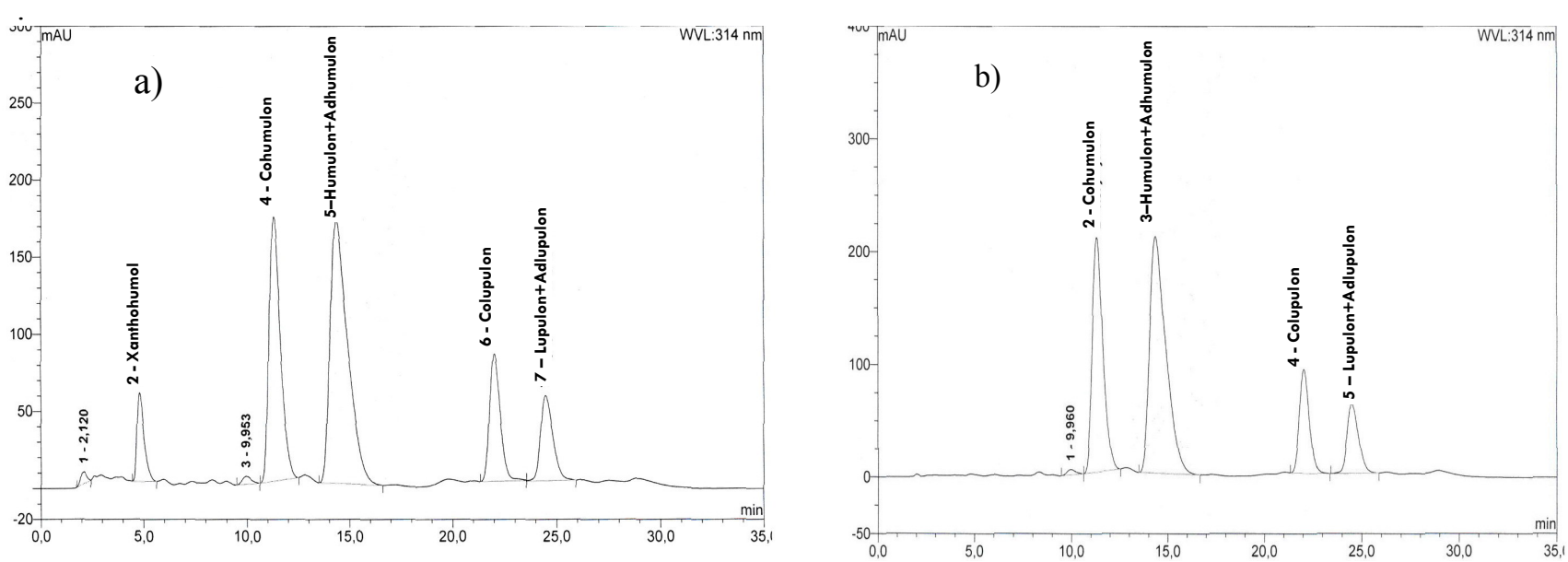

Figure 3 Chromatograms of the composition of bitter substances extracts of hops: a) Ethanol extract hops of the Hercules variety; b) $\mathrm{CO}_{2}$-extract hops of the Hercules variety.

Always the best quality has beer which made from hops with a content of polyphenols do not less than $4.5 \%$ (Goiris et al., 2014).

The content of general polyphenols in the hop products according to Table 1 changed from 4.21 till $11.03 \%$. However, the main property of the hop products for this indicator determined do not by their general content, but by common quantity polyphenols per $1 \mathrm{~g}$ of $\alpha$-acids. If in the cones of hop of aromatic varieties this value ranges from 1.0 till 1.3 , hop pellets type 90 from 0.8 till 1.3 , but in hop pellets type 90 bitter varieties from 0.3 till 0.4 , that less on the $2.5-3.0$ times. The studies showed that polyphenolic compounds were absent in ethanol and $\mathrm{CO}_{2}$ extracts. Our studies confirmed investigations other scientists, which indicate the absence or insignificant content of polyphenolic compounds in these hops products.

In connection with this, for normal implementation of the brewing process and obtaining a full-fledged beer, it is necessary to add a certain quantity of cones or pellets of hop. Complex biochemical researches of hops and hop product of diffrent varieties with the used of modern biochemical methods give possible to established that hops and hop products of different varieties have different biochemical composition and hence different brewing value. This testified the fact that at the norms of different hop products of individual varieties with the same content of a-acids in the wort added different quantity of valuable for brewing components of hops. Consequently, the quality of beer produced by the same technology, but with the use of hops and hop products of different varieties can differ significantly.

Therefore, along with studies on the biochemical composition of pressed cones of hop and hop products of different varieties of domestic and foreign production, studies of their influence on the quality of the finished beer were conducted.

As the results of the researches, all obtained samples of beer were produced according the classical technology of light unfiltered beer which requirements of method described in state standard of Ukraine 3888:2015 (DSTU 3888:2015). The physical and chemical indexes of the beer samples from the researches varieties of pressed cones of hop and different hop products presented in Table 2 .

The analysis of physical and chemical indicators of beer quality shows that the degree of using of complex of valuable substances of hops and hop products was significantly higher in pellets and extracts than in native hop cones (Table 2). From the data which were presented we can see if used hop pellets type 90 of the Ukrainian bitter Alta variety in the hopped wort and beer, there were higher general indicators of bitterness and polyphenols than we using hops pellets type 90 of bitter Hercules type of German production. The norm at the same time was the same, taking into account only the content of alpha acids. Consequently, such results were due to the higher content of the beta fraction and polyphenols in pellets of the bitter Alta variety. The maximum amount of bitterness of beer provided pellets of hop type 45 of the Tradition variety, and the maximum amount of polyphenolic compounds in the wort and beer obtained with using hops cones and pellets of type 90 Slavianka and Zagrava varieties. Since there are not polyphenols in the extracts therefore in the wort and the finished beer which were produced from them obtained the least quantity of polyphenolic compounds.

In the process of basic and additional fermentation of beer the amount of bitter substances and polyphenols decreased (Lyashenko, 2002; Pavlovič et al., 2012; Michalowska, 2017). Thus, the amount of bitterness from wort to finished beer decreased in the range of $14.5-23.3$ $\%$ and total polyphenols $15.2-20.9 \%$.

The organoleptic assessment of the quality of the beer samples which were determined by the tasting commission, showed that was significantly different in taste, in the character of bitterness and aroma (Table 3).

All samples of beer (Table 3) were good or excellent quality and did not significantly differ. Each sample of beer had different taste, aroma or quality and fullness of bitterness. The quantity of pressed cones of hop (hop products) for adding to the wort calculated depend on the content of alpha acids in accordance with the branch Instruction TI 10-04-06-136-87 (TI, 1998). 
Table 2 Physico-chemical indexes of the beer samples.

\begin{tabular}{|c|c|c|c|c|c|}
\hline No. & $\begin{array}{l}\text { Grade of beer } \\
\text { Variant of the } \\
\text { experiment }\end{array}$ & $\begin{array}{c}\text { Bitterness of } \\
\text { wort, unit EBC }\end{array}$ & $\begin{array}{c}\text { Content } \\
\text { polyphenols in } \\
\text { the wort, } \\
\mathrm{mg} / \mathbf{d m}^{3}\end{array}$ & $\begin{array}{c}\text { Bitterness of } \\
\text { beer, unit EBC }\end{array}$ & $\begin{array}{c}\text { Content } \\
\text { polyphenols in } \\
\text { the beer, } \\
\mathrm{mg} / \mathbf{d m}^{3}\end{array}$ \\
\hline \multirow[t]{2}{*}{1} & $\begin{array}{l}\text { Cones of hop of the } \\
\text { Slavyanka variety }\end{array}$ & $27.72 \pm 0.06 \mathrm{a}^{*}$ & $232.42 \pm 0.22 \mathrm{a}$ & $21.60 \pm 0.64 \mathrm{a}$ & $202.10 \pm 0.15 \mathrm{a}$ \\
\hline & $\begin{array}{l}\text { Cones of hop of the } \\
\text { Nationalny variety }\end{array}$ & $29.30 \pm 1.02 b$ & $240.64 \pm 0.34 b$ & $25.52 \pm 0.24 \mathrm{~b}$ & $200.44 \pm 0.25 b$ \\
\hline 3 & $\begin{array}{l}\text { Cones of hop of the } \\
\text { Zagrava variety }\end{array}$ & $28.04 \pm 0.05 \mathrm{a}$ & $281.61 \pm 0.50 \mathrm{c}$ & $26.64 \pm 0.34 \mathrm{c}$ & $222.63 \pm 0.30 \mathrm{c}$ \\
\hline 4 & $\begin{array}{l}\text { Cones of hop of the } \\
\text { Alta variety }\end{array}$ & $27.33 \pm 1.06 \mathrm{a}$ & $232.43 \pm 0.16 \mathrm{a}$ & $23.43 \pm 0.38 \mathrm{~d}$ & $188.14 \pm 0.10 \mathrm{~d}$ \\
\hline 5 & $\begin{array}{l}\text { Pellets of type } 90 \\
\text { Slavyanka variety }\end{array}$ & $36.00 \pm 0.05 \mathrm{c}$ & $240.60 \pm 0.35 b$ & $26.22 \pm 0.18 \mathrm{bc}$ & $202.92 \pm 0.15 \mathrm{a}$ \\
\hline 6 & $\begin{array}{l}\text { Pellets of type } 90 \\
\text { Nationalny variety }\end{array}$ & $32.72 \pm 1.10 \mathrm{~d}$ & $219.42 \pm 0.40 \mathrm{~d}$ & $27.73 \pm 0.75 \mathrm{e}$ & $191.63 \pm 0.20 \mathrm{e}$ \\
\hline 7 & $\begin{array}{l}\text { Pellets of type } 90 \\
\text { Zagrava variety }\end{array}$ & $29.44 \pm 0.04 \mathrm{~b}$ & $244.30 \pm 0.18 \mathrm{e}$ & $27.32 \pm 0.24$ ce & $211.52 \pm 0.40 \mathrm{f}$ \\
\hline 8 & $\begin{array}{c}\text { Pellets of type } 90 \text { Alta } \\
\text { variety }\end{array}$ & $29.90 \pm 0.05 \mathrm{~b}$ & $188.92 \pm 0.26 \mathrm{f}$ & $26.04 \pm 0.35 \mathrm{bc}$ & $170.11 \pm 0.20 \mathrm{~g}$ \\
\hline 9 & $\begin{array}{l}\text { Pellets of type } 45 \\
\text { Tradition variety }\end{array}$ & $33.92 \pm 0.08 \mathrm{e}$ & $227.10 \pm 0.30 \mathrm{~g}$ & $31.04 \pm 0.25 \mathrm{f}$ & $191.10 \pm 0.15 \mathrm{e}$ \\
\hline 10 & $\begin{array}{c}\text { Pellets of type } 45 \text { Spalt } \\
\text { Select variety }\end{array}$ & $29.84 \pm 0.01 \mathrm{~b}$ & $206.62 \pm 0.28 \mathrm{~h}$ & $28.42 \pm 0.37 \mathrm{eg}$ & $194.33 \pm 0.10 \mathrm{~h}$ \\
\hline 11 & $\begin{array}{l}\text { Pellets of type } 90 \\
\text { Hercules variety }\end{array}$ & $33.20 \pm 0.06 \mathrm{de}$ & $191.93 \pm 0.17 \mathrm{i}$ & $28.64 \pm 0.40 \mathrm{eg}$ & $153.32 \pm 0.28 \mathrm{i}$ \\
\hline 12 & $\begin{array}{l}\text { Ethanol extract hops of } \\
\text { the Hercules variety }\end{array}$ & $32.90 \pm 0.08 \mathrm{de}$ & $171.72 \pm 0.25 \mathrm{j}$ & $28.82 \pm 0.12 \mathrm{~g}$ & $145.54 \pm 0.22 \mathrm{j}$ \\
\hline \multirow[t]{4}{*}{13} & $\begin{array}{l}\mathrm{CO}_{2} \text {-extract hops of } \\
\text { the Hercules variety }\end{array}$ & $35.42 \pm 0.09 \mathrm{f}$ & $185.32 \pm 0.32 \mathrm{k}$ & $29.34 \pm 0.10 \mathrm{~g}$ & $149.92 \pm 0.16 \mathrm{k}$ \\
\hline & minimum & 27.33 & 171.72 & 20.96 & 145.54 \\
\hline & maximum & 36.00 & 281.61 & 30.79 & 222.63 \\
\hline & mean & 31.21 & 220.23 & 26.98 & 186.44 \\
\hline
\end{tabular}

Note: *value \pm SD are means of three repetitions, *Mean values followed by different letters are statistically different at $p<0.05$.

Hops and hop products added at the rate $50 \mathrm{mg}$ of bitter substances per $1 \mathrm{dm}^{3}$ of wort. However, the taste of beer and the quality of bitterness in different samples were different. As indicated results researches of biochemical composition, the reason of this difference in the content of bitter substances and other components in the varieties of hops and hop products that added to wort. At the beer boiled added various hops products with the same content of alpha acids but different content of other valuable brewing components of hop. The quality of beer which was produced by one technology, but using different types of hop products was significantly differ. Our studies were correlation with other researches of the domestic and foreign scientists (Lyashenko, 2002; Sheiko et al., 2019), which established that beer made from hops of various varieties was significantly different in character of bitterness, taste and aroma. The reason of this the peculiarity of the biochemical composition of bitters substances, polyphenolic compounds and essential oils of hop of aromatic and bitter varieties. Different ratio of components of these compounds differently affects on the taste and aromatics of beer. With taking into account, for determine the suitability of hops and hop products for beer making need carry out their complex comprehensive technological assessment of biochemical composition of the hops products.

According to the results of the tasting (Table 3), all samples of beer had a pleasant fresh beer flavor. The hop flavor was well presented in the beer with hopped wort by cones of pressed hop and pellets of hop type 90 varieties Slavyanka, Nationalny, Zagrava and Alta. In the samples of beer made from ethanol extract and $\mathrm{CO}_{2}$-extract of hop of the Hercules variety, the aroma of hops was almost absence. The beer made from cones of pressed hop and pellets of hop type 90 varieties Slavyanka and Nationalny for bitterness and taste quite similar to each other. The bitterness was very light, delicate, soft, but in the beer made from pellets of hop type 90 varieties Slavyanka and Nationalny somewhat excess. The taste of this beer was full, harmonious. Beer obtained by adding to the wort pressed cones and pellets of type 90 of hop variety Zagrava for the quality of bitterness and taste similar. The beer has little harmonious taste and delicate, pleasant, balanced bitterness. But the bitterness of beer with added to the wort pellets type 90 of the Zagrava variety was more intense. When added to the wort pressed cones of hop of the Alta variety, pellets of hops type 90 varieties Alta and Hercules beer had rough bitter. Fullness of taste not detected. 
Table 3 Organoleptic (tasting) evaluation of beer, depending on the characteristics of the hops and hop products, points. Names of quality indicators

Taste

\begin{tabular}{|c|c|c|c|c|c|c|c|c|c|}
\hline No. & $\begin{array}{c}\text { Grade of beer } \\
\text { Variant of the experiment }\end{array}$ & 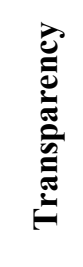 & $\frac{\grave{\theta}}{\dot{\theta}}$ & 咲 & 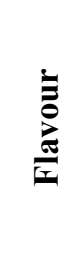 & $\stackrel{\tilde{E}}{\Xi}$ & 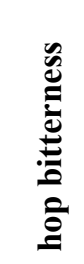 & 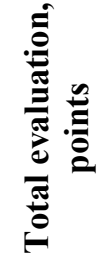 & 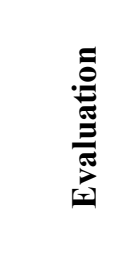 \\
\hline 1 & $\begin{array}{c}\text { Cones of hop of the Slavyanka } \\
\text { variety }\end{array}$ & 3.0 & 3.0 & 5.0 & 3.7 & 4.5 & 4.4 & 23.6 & excellent \\
\hline 2 & $\begin{array}{c}\text { Cones of hop of the Nationalny } \\
\text { variety }\end{array}$ & 3.0 & 3.0 & 5.0 & 3.8 & 4.0 & 4.2 & 23.0 & excellent \\
\hline 3 & Cones of hop of the Zagrava variety & 3.0 & 3.0 & 5.0 & 3.4 & 3.9 & 4.0 & 22.3 & excellent \\
\hline 4 & Cones of hop of the Alta variety & 3.0 & 3.0 & 5.0 & 3.5 & 3.5 & 3.3 & 21.3 & well \\
\hline 5 & Pellets of type 90 Slavyanka variety & 3.0 & 3.0 & 5.0 & 3.9 & 4.2 & 4.3 & 23.4 & excellent \\
\hline 6 & Pellets of type 90 Nationalny variety & 3.0 & 3.0 & 5.0 & 3.8 & 4.2 & 4.2 & 23.2 & excellent \\
\hline 7 & Pellets of type 90 Zagrava variety & 3.0 & 3.0 & 5.0 & 3.6 & 3.9 & 4.1 & 22.6 & excellent \\
\hline 8 & Pellets of type 90 Alta variety & 3.0 & 3.0 & 5.0 & 3.5 & 3.5 & 3.5 & 21.5 & well \\
\hline 9 & Pellets of type 45 Tradition variety & 3.0 & 3.0 & 5.0 & 3.7 & 4.0 & 4.0 & 22.7 & excellent \\
\hline 10 & Pellets of type 45 Spalt Select variety & 3.0 & 3.0 & 5.0 & 3.8 & 4.1 & 4.5 & 23.4 & excellent \\
\hline 11 & Pellets of type 90 Hercules variety & 3.0 & 3.0 & 5.0 & 2.2 & 2.9 & 2.9 & 19.0 & well \\
\hline 12 & $\begin{array}{c}\text { Ethanol extract hops of the Hercules } \\
\text { variety }\end{array}$ & 3.0 & 3.0 & 5.0 & 3.0 & 3.3 & 3.5 & 20.8 & well \\
\hline 13 & $\begin{array}{c}\mathrm{CO}_{2} \text {-extract hops of the Hercules } \\
\text { variety }\end{array}$ & 3.0 & 3.0 & 5.0 & 3.1 & 3.0 & 3.4 & 20.5 & well \\
\hline
\end{tabular}

The beer made from pellets of hop type 45 varieties Tradition had bound, balanced bitterness with a pleasant hops aroma. Adding to the wort the pellets of the hops type of the 45 variety Spalt Seleck provided the beer with fresh hop flavor, full harmonious taste and bound, pleasant, balanced bitterness.

Beer produced for the ethanol and $\mathrm{CO}_{2}$-extracts of the Hercules variety of taste and bitterness were almost indistinguishable. The bitterness was rough, exceed. Beer was empty, without fullness of taste.

\section{CONCLUSION}

Complex researches of hops and hop products of various varieties with used of modern biochemical methods allow was established that hops and hop products of different varieties have different biochemical composition and hence difference brewing value. Differences depend on the absolute values of such parameters as the mass fraction of $\alpha$-acids, $\beta$-acids and their composition, xanthohumol, general polyphenols, essential oils, the ratio of their valuable components of hops: $\beta$-acids to $\alpha$-acids, and also the general quantity of polyphenols and essential oils per unit of $\alpha$-acids.
Hops pellets of type 90 of domestic production contain the whole complex of necessary for brewing substances which were equivalent to hop cones. Characteristic feature of pressed cones of hop and hop pellets of type 90 and type 45, in particular of aromatic varieties, were high positive coefficient of aromatics between the content of $\beta$ - and $\alpha$-acids, ranging from 0.9 till 1.8. In opposite in pellets and extracts in hop cones presented more essential oils per $1 \mathrm{~g}$ of $\alpha$-acids, which provides obtained more aromatic beer.

Hops pellets of the type 45 of foreign production enriched in the content of $\alpha$-acids in their composition contained less amount of essential oil than hop cones and hop pellets type 90, which associated with the technology of obtaining pellets of this type.

Ethanol and $\mathrm{CO}_{2}$ extracts had concentration of $\alpha$-acids up to $50 \%$ or more, which ensured the benefits of these products during storage, transportation and using in brewing. But these extracts do not had the required quantity of polyphenolic compounds of hops necessary for the normal implementation of the brewing process and obtaining full-fledged beer. They contained less quantity of essential oil, but it did not enough for the optimal ratio with alpha acids. Therefore, when making 
beer, it is necessary to add certain quantity of cones or hops granules.

Technological assessment of the selection varieties of pressed cones of hop and hop products showed that all presented thin-aromatic and aromatic hops types Slavianka, Nationalny, Zagrava and pellets type 90, made from them and also pellets of type 45 varieties Tradition and Spalt Select were suitable both for self-use in brewing and for improve the taste of beer in combination with other processed products. Beer made from hops pellets, especially the Zagrava variety, had an excess of bitterness, therefore to norm pellets for beer production due to with an economy of up to $10 \%$. The individual used of pressed cones of hop and pellets of the bitter variety Alta and Hercules does not allow obtained the bitterness of beer of excellent quality. Ethanol and $\mathrm{CO}_{2}$ extracts for self-use in brewing were not suitable. It was possible to recommend their using in combination with cones and pellets of aromatic varieties, while adhering to certain technology.

\section{REFERENCES}

Bober, A., Podpryatov, G., Koltunov, V., Venher, O. 2015. Resource potential of hoped-for-hopped regions in Ukraine and their competitiveness. Bioresources and nature management, vol. 7, no. 1-2, p. 80-91.

DSTU 3888:2015. State standard of Ukraine. Beer. General specifications. Quality management systems Requirements.

DSTU EN 14164:2019. State standard of Ukraine. Food products. Determination of substances by high performance liquid chromatography. Quality management systems Requirements.

Ferk, F., Huber, W. W., Filipič, M., Bichler, J., Haslinger, E., Mišík, M., Nersesyan, A., Grasl-Kraupp, B., Žegura, B., Knasmüller, S. 2010. Xanthohumol, a prenylated flavonoid contained in beer, prevents the induction of preneoplastic lesions and DNA damage in liver and colon induced by the heterocyclic aromatic amine amino-3-methyl-imidazo[4,5f]quinoline (IQ). Mutation Research - Fundamental and Molecular Mechanisms of Mutagenesis, vol. 691, no. 1-2, p. 17-22. https://doi.org/10.1016/j.mrfmmm.2010.06.006

Goiris, K., Jaskula-Goiris, B., Syryn, E., Van Opstaele, F., De Rouck., G, Aerts., G, De Cooman, L. 2014. The flavoring potential of hop polyphenols in beer. Journal of the American Society of Brewing Chemists, vol. 72, no. 2, p. 135-142. https://doi.org/10.1094/ASBCJ-2014-0327-01

Jaskula, B., Goiris, K., De Rouck, G., Aerts, G., De Cooman, L. 2007. Enhanced quantitative extraction and HPLC determination of hop and beer bitter acids. J. Inst. Brew, vol. 113, no. 4, p. 381-390. https://doi.org/10.1002/j.2050-0416.2007.tb00765.x

Kábelová-Ficová, H., Stanislav, K., Gregor, T., Fišera, M., Golian, J., Kubáň, V., Šopík, T. 2017. Preparation of malts for production of special beers. Potravinarstvo Slovak Journal of Food Sciences, vol. 11, no. 1, p. 441-445. https://doi.org/10.5219/773

Lyashenko, N. I. 2002. Hops and hop products biochemistry. ZHYTOMYR, UKRAINE : Polissja, 388 p.

Lyashenko, N. I., Protsenko, L. V. 2009. Prenylflavonoids of hops and beer. Agro-industrial production of Polissya, vol. 2, p. 52-57.

Malowicki, M., Shellhammer, T. 2006. Factors affecting hop bitter acid isomerization kinetics in a model wort boiling system. J. Am. Soc. Brew. Chem., vol. 64, p. 29-32. https://doi.org/10.1094/ASBCJ-64-0029

Michałowska, D. 2017. Hop Storage Index (HSI) wskaźnik jakości chmielu i granulatów chmielowych. Przem. Ferm. Owoc, vol. 61, no. 4, p. 39-40

Pavlovič, V., Pavlovič, M., Čerenak, A., Košir, I., Čeh, B., Rozman, Č., Turk, J., Pazek, K., Krofta, K., Gregorič, G. 2012. Environment and weather influence on quality and market value of hops. Plant Soil Environ, vol. 58, p. 155160. https://doi.org/10.17221/499/2011-PSE

Protsenko, L., Litvynchuk, S. 2017. Features of using hops and $\mathrm{CO}_{2}$-extract in brewing. Ukrainian food journal, vol. 6, no. 1, p. 77-84. https://doi.org/10.24263/2304-974X2017-6-1-9

Protsenko, L., Rudyk, R., Hryniuk, T., Vlasenko, A., Protsenko, A., Litvynchuk, S., Ovadenko, O. 2018. Beer enrichment with biologically active hop Compounds. Ukrainian Journal of Food Science, vol. 7, no. 1, p. 65-78. https://doi.org/10.24263/2304-974X-2018-7-1-7

Protsenko, L. V., Lyashenko, N. I ., Meletyev, A. E. 2007. Improving the quality of beer with the use of hop preparations. Food industry, vol. 9, p. 10-13.

Pryimachuk, T., Protsenko, A., Rudyk, R., Shtanko, T. 2018. Beer and Hops Industry of Ukraine: Conjuncture and Integration. Bulletin of Agrarian Science, vol. 4, p. 61-67. https://doi.org/10.31073/agrovisnyk201804-10

Punčocháŕová, L., Pořízka, J., Diviš, P., Štursa, V. 2019. Study of the influence of brewing water on selected analytes in beer. Potravinarstvo Slovak Journal of Food Sciences, vol. 13, no. 1, p. 507-514. https://doi.org/10.5219/1046

Shanina, O., Galyasnyj, I., Gavrysh, T., Dugina, K., Sukhenko, Y., Sukhenko, V., Miedviedieva, N., Mushtruk, M., Rozbytska, T., Slobodyanyuk, N. 2019. Development of gluten-free non-yeasted dough structure as factor of bread quality formation. Potravinarstvo Slovak Journal of Food Sciences, vol. 13, no. 1, p. 971-983. https://doi.org/10.5219/1201

Sheiko, T., Tkachenko, S., Mushtruk, M., Vasyliv, V., Deviatko, O., Mukoid, R., Bilko, M., Bondar, M. 2019. The Studying the processing of food dye from beet juice. Potravinarstvo Slovak Journal of Food Sciences, vol. 13, no. 1, p. 688-694. https://doi.org/10.5219/1152

TI. 1988. Technological instructions for use in brewing hops and its products. 1988. TI 10-04-06-136-87, Gosagroprom, Moscow.

Yang, M., Li, N., Li, F., Zhu, Q., Liu, X., Han, Q., Wang, Y., Chen, Y., Zeng, X., Lv, Y., Zhang, P., Yang, C., Liu, Z. 2013. Xanthohumol, a main prenylated chalcone from hops, reduces liver damage and modulates oxidative reaction and apoptosis in hepatitis $\mathrm{C}$ virus infected Tupaia belangeri. Int. Immunopharmacol., vol. 16, p. 466-474. https://doi.org/10.1016/j.intimp.2013.04.029

Zheplinska, M., Mushtruk, M., Vasyliv, V., Deviatko, O. 2019. Investigation of the process of production of crafted beer with spicy and aromatic raw materials. Potravinarstvo Slovak Journal of Food Sciences, vol. 13, no. 1, p. 806-814. https://doi.org/10.5219/1183

Żołnierczyk, A., Baczyńska, D., Potaniec, B., Kozłowska, J., Grabarczyk, M., Woźniak, E., Anioł, M. 2017. acyl derivatives. Medicinal Chemistry Research, vol. 26, no. 8, p. 1764-1771. https://doi.org/10.1007/s00044-017-1887-9 


\section{Contact address:}

Anatolii Bober, National University of Life and Environmental Sciences of Ukraine, Agrobiological Faculty, Department of storage, processing and standardization of plant products after prof. B.V. Lesik, Heroiv Oborony Str., 13, Kyiv, 03041, Ukraine, Tel.: +380674056632,

E-mail: Bober 1980@i.ua

ORCID: http://orcid.org/0000-0003-1660-1743

Mykola Liashenko, Institute of Agriculture Polissya, Academy of Sciences of Ukraine, Department biochemistry of hops and beer, Kiev highway, Str., 131, Zhitomir, 10007, Ukraine, Tel.: +380679573602,

E-mail: mikola lyashenko@ukr.net

ORCID: https://orcid.org/0000-0003-0294-6484

Lidiia Protsenko, Institute of Agriculture Polissya, Academy of Sciences of Ukraine, Department biochemistry of hops and beer, Kiev highway, Str., 131, Zhitomir, 10007, Ukraine, Tel.: +380679870951,

E-mail: mikola lyashenko@ukr.net

ORCID: https://orcid.org/0000-0002-7746-0270

Natalia Slobodyanyuk, National University of Life and Environmental Sciences of Ukraine Department of Standardization and Certifying of Agricultural Products, Heroiv Oborony str, 15, 03041, Kyiv, Ukraine, Tel.: +380982768508,

E-mail: slob2210@ukr.net

ORCID: https://orcid.org/0000-0002-7724-2919

Liudmyla Matseiko, National University of Life and Environmental Sciences of Ukraine, Agrobiological Faculty, Department of storage, processing and standardization of plant products after prof. B.V. Lesik, Heroiv Oborony str., 13, Kyiv, 03041, Ukraine, Tel.: +380979262764 ,

E-mail: org section@nubip.edu.ua

ORCID: https://orcid.org/0000-0001-9693-0736
Nadiia Yashchuk, National University of Life and Environmental Sciences of Ukraine, Agrobiological Faculty, Department of storage, processing and standardization of plant products after prof. B.V. Lesik, Heroiv Oborony Str., 13, Kyiv, 03041, Ukraine, Tel.: +380991471582,

E-mail: yazchsuk@,rambler.ru

ORCID: http://orcid.org/0000-0002-5819-2813

Sergiy Gunko, National University of Life and Environmental Sciences of Ukraine, Agrobiological Faculty, Department of storage, processing and standardization of plant products after prof. B.V. Lesik, Heroiv Oborony Str., 13, Kyiv, 03041, Ukraine, Tel.: +380502553897,

E-mail: cgunko@gmail.com

ORCID:https://orcid.org/0000-0001-8264-5176

*Mikhailo Mushtruk, National University of Life and Environmental Sciences of Ukraine, Faculty of Food Technology and Quality Control of Agricultural Products, Department of Processes and Equipment for Processing of Agricultural Production, Heroev Oborony Str., 12 B, Kyiv, 03040, Ukraine, Tel.: +38099412606, E-mail: mixej.1984@ukr.net

ORCID: https://orcid.org/0000-0002-3646-1226

Corresponding author: * 